\title{
Dutch Disease or Monetarist Medicine?: The British Economy under Mrs. Thatcher
}

\author{
K. Alec Chrystal
}

$\mathbf{T}$

HE performance of the British economy over the past five years has been the object of worldwide curiosity. Much publicity has been focused on the government of Margaret Thatcher and her apparently radical departure from the policies pursued by her predecessors. This alleged policy departure is sometimes considered a "monetarist experiment." ${ }^{2}$ Chart 1 illustrates some of the major macroeconomic changes in Britain since Mrs. Thatcher's election to Prime Minister. Inflation first rose through 1980, then fell by 1983 to its lowest level since the mid 1960 s. In contrast, unemployment rose after 1979 to its highest level since the 1930s. By the end of 1983, unemployment was more than double that following the previous worst recession $(1973-75)$ in the postwar period.

Critics of Mrs. Thatcher claim that these events are primarily the result of the tight aggregate demand (monetarist) policies of her government and, further, that the price paid for reducing inflation has been too

$K$. Alec Chrystal, professor of economics-elect, University of Sheffield, England, is a visiting scholar at the Federal Reserve Bank of St. Louis. Leslie Bailis Koppel provided research assistance.

'Mrs. Thatcher came to power five years ago on May 3,1979 . She was reelected for a second term in June 1983 and may stay in office until June 1988 without recourse to a further general election.

2See, for example, Gould, Mills and Steward (1981), Kaidor (1982), and Buiter and Miller (1981). high. The purpose of this paper is to point out that this interpretation of events is misleading.

An important feature of the changing employment levels in Britain has been that job losses occurred almost entirely in the manufacturing sector. In 1979, this sector provided about 28 percent of total employment. Between the end of 1978 and the end of 1982, there was a 1.4 million rise in the number of unemployed. Over the same period, the number employed in manufacturing industries fell by 1.5 million. This job loss can be traced to a substantial and sustained collapse of manufacturing production (chart 2) between late 1979 and the end of 1980 .

Thus, any explanation of unemployment's steep rise in Britain must be able to explain the collapse in the manufacturing sector, a collapse that was essentially completed within 18 months of Mrs. Thatcher taking office. Neither monetary nor fiscal policy, alone or taken fogether, has been so tight as to explain sufficiently what has happened in Britain. Rather, a more likely contributor to unemployment comes from the structural changes in the British economy caused by North Sea oil production. The scenario is now widely termed the "Dutch Disease," so-called because of the negative impact that Dutch oil and gas production had on employment and output in the non-oil traded goods sector of the Netherlands' economy. 


\section{Chart 1}

\section{Inflation and Unemployment}

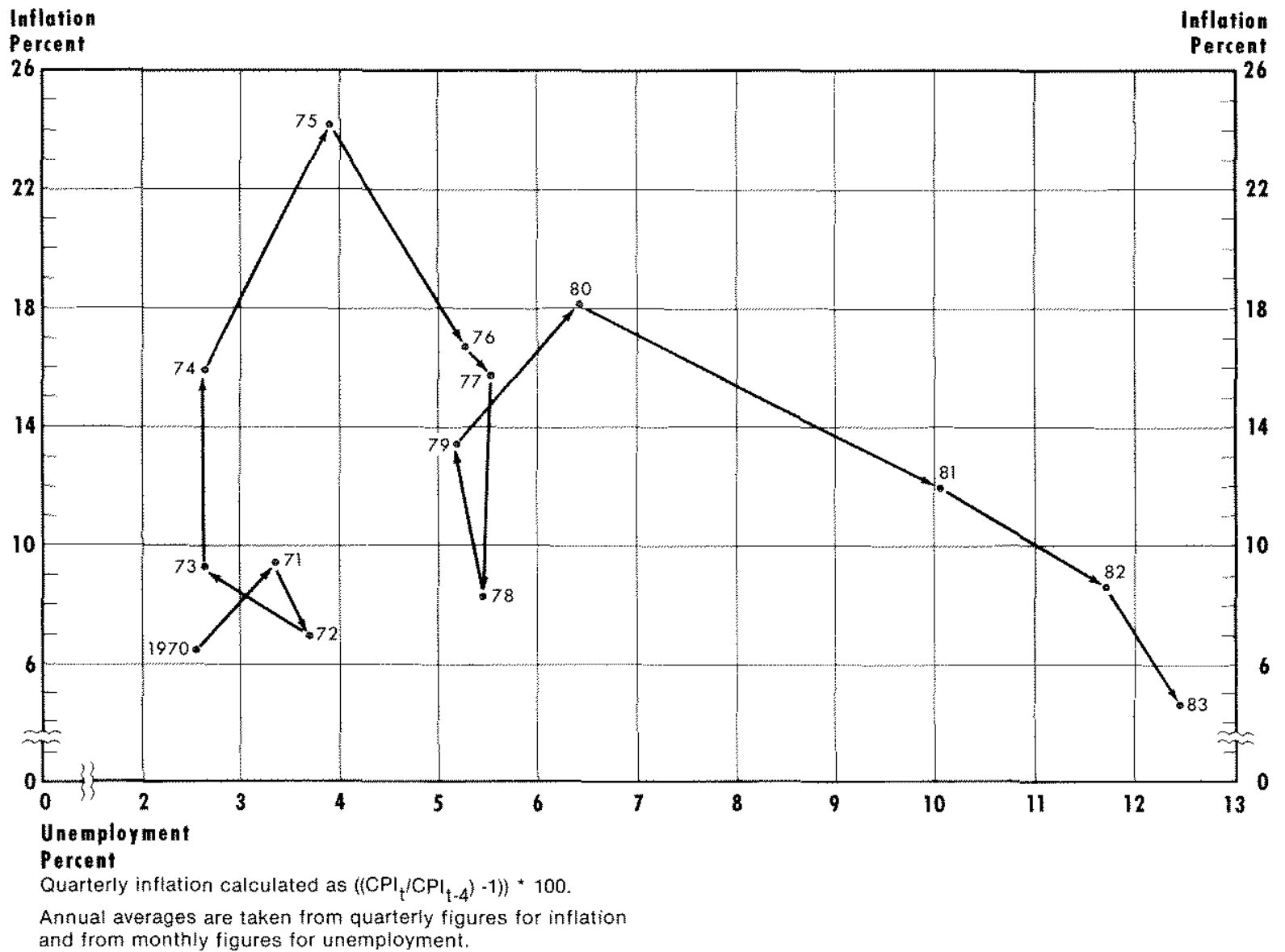

Before discussing the impact of North Sea oil production on the British economy, however, it is necessary to show why two other widely claimed causes British policies and the worldwide recession - are inadequate explanations.

\section{BDITAIN BEFORE THATCHER}

Macroeconomic policy in the 1950 s and 1960 s was dominated by the commitment to maintain a fixed exchange rate. Fiscal policy was used to stimulate the economy whenever there appeared to be slack; expansion, on the other hand, was constrained by the balance of payments. Periodic runs on Britain's foreign exchange reserves led to policy reversals, causing a budgetary cycle of expansion and contraction that earned the nickname of "stop-go." A stable exchange rate was maintained, however, for nearly two decades (1949-67). Indeed, in retrospect, this period seems like a golden age. Inflation averaged 3 percent, unemployment averaged less than 2 percent and was sometimes below 1 percent, and average real incomes grew about 3 percent per year.

Monetary policy in this period was subordinated to the twin requirements of maintaining the exchange rate and funding public sector borrowing. The main policy instrument was the Bank of England's discount rate (Bank Ratel, though this was augmented periodicaly by quantitative ceilings on bank lending. These ceilings were particularly important following the November 1967 devaluation of sterling until 1971."

\section{Heath's "Dash for Growth"}

In mid-1970, when the Labour government of Harold Wilson lost a general election to the Conservative party

In both the 1960 s and 1970s, monetary and fiscal policies were augmented from time to time by incomes policies which attempted to regulate the growth rate of wages. There is some evidence that these policies temporarly restrained wage increases, but had no long-run impact on wage and price intlation. See Henry and Omerod (1978). 
Chork 2

\section{Manufacturing Production Index}

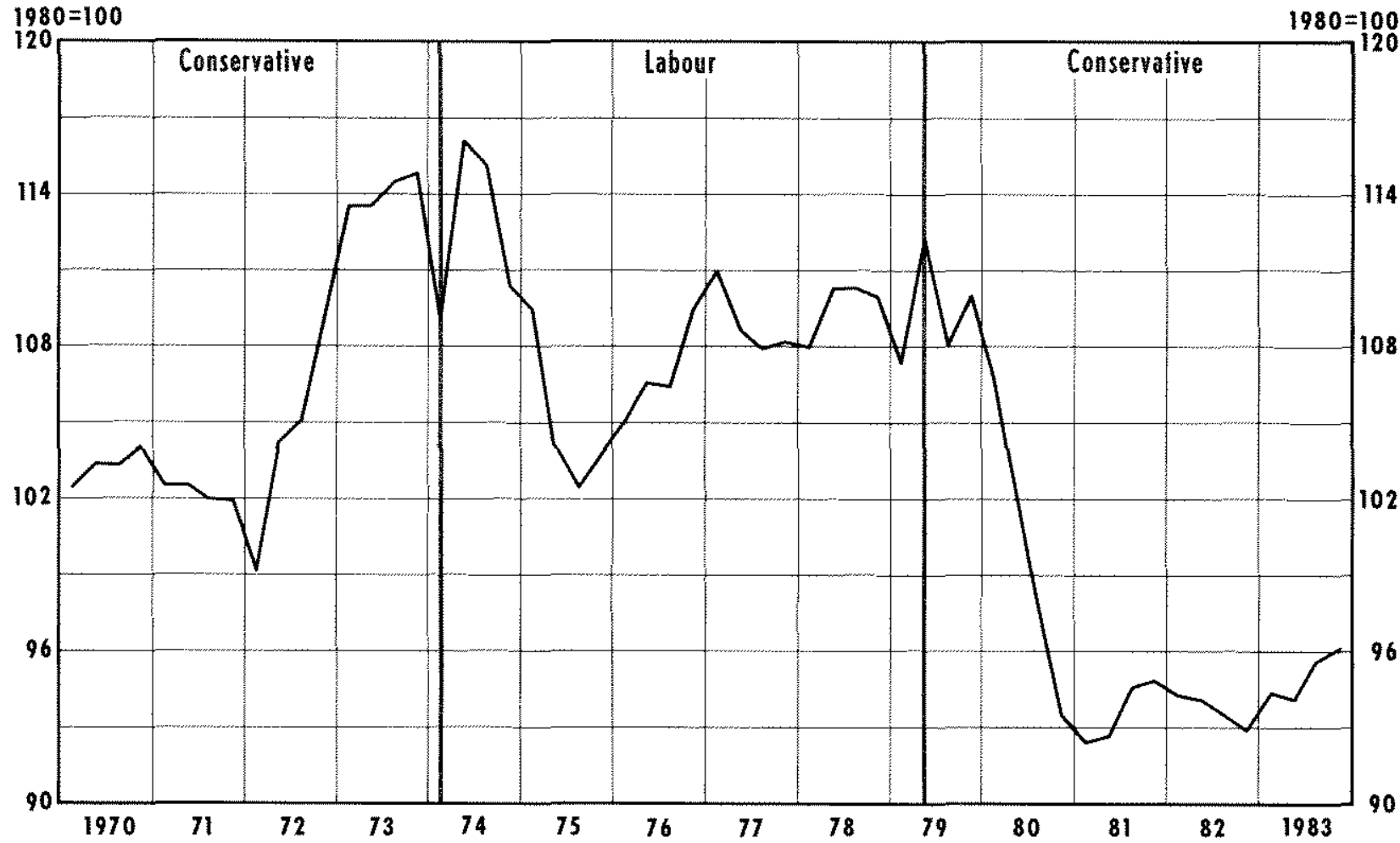

led by Edward Heath, the British economy was in good shape. Both the balance of payments and the government budget were in surplus. Inflation (6 percent) and unemployment ( 2.2 percent), although high by $1960 \mathrm{~s}$ standards, were by no means at crisis levels - or so it seems in retrospect.

As unemployment drifted upward through 1971 , however, the Heath government embarked upon a stimulative macroeconomic policy known alternatively as the "dash for growth" or the "Barber boom." The stimulation took two forms. First, monetary policy became expansionary in September 1971 following the introduction of a reform package known as Competition and Credit Control. This program removed ceilings on bank lending without replacing them with an effective alternative control mechanism. ${ }^{5}$ As a result,

${ }^{4}$ The Chancellor of the Exchequer, chiet minister in the Treasury, during the Heath government (June 1970-February 1974) was Anthony (later Lord) Barber, appointed July 26, 1970.

${ }^{5}$ See Hall (1983) for a detailed discussion of the scheme. The authorities presumably thought the monetary expansion would be temporary following the removal of ceilings. If proved, however, to be both substantial and sustained. money and credit expanded rapidly. Through 1972 and 1973, the annual growth rate of sterling $M 3$ reached levels well in excess of 20 percent isee chart 3$)^{6}$

Second, an expansionary budget was introduced in March 1972. This largely involved cuts in personal taxation, but was later augmented by a substantial expansion in public sector investment programs.

Underlying this dash for growth was the belief that the growth of the British economy had been artificially constrained by the fixed exchange rate (or, equivalently, the balance of payments). In the past, restrictive fiscal policy had to be introduced every time there was a significant run on foreign exchange reserves.

Floating the exchange rate became acceptable, however, following the measures introduced by President

The monetary aggregates referred to are defined as follows: $M 1=$ notes and coins in circulation with the public + U.K. private sector sterling sight deposits; sterling $M 3=M 1+$ private sector sterling time deposits + public sector deposits. Sterling M3 was the aggregate targeted after 1976, though after 1980 the authorities claimed to be monitoring both narrower and broader aggregates as well as sterling M3. 


\section{Chart 3}

\section{Annual Growth Rates of MI and Sterling M3}

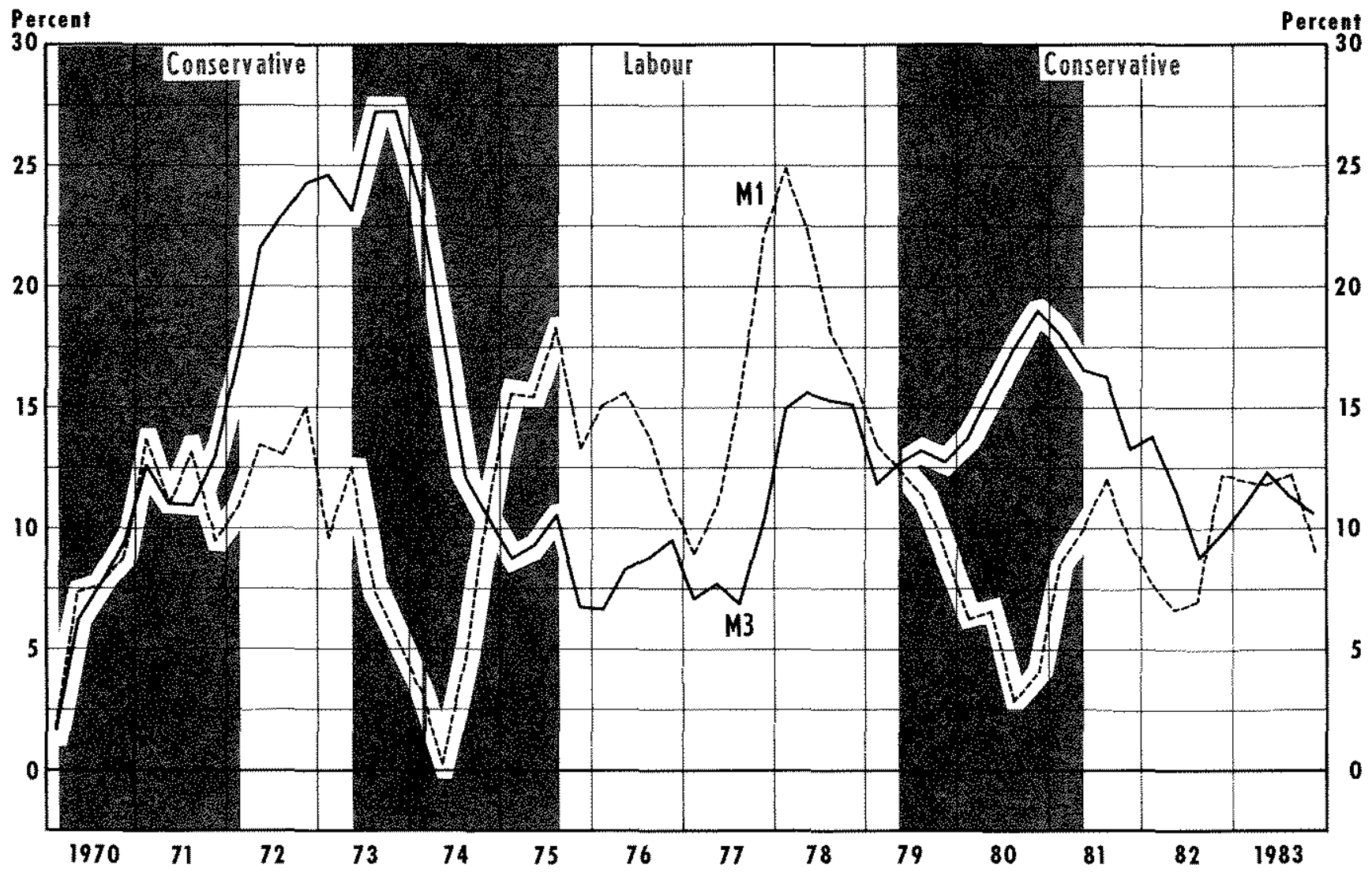

Shaded areas represent recessions, defined os the contraction phose of coincident econamic indicators.

Nixon on August 15, 1971, which among other things led to the floating of the U.S. dollar in foreign exchange markets. The pound floated from August 23, 1971, was repegged following the Smithsonian Agreement of December, but floated again on June 23,1972 , after a run on reserves. The float, which was introduced as a temporary measure, has continued ever since.

The expansionary policies were successful for a short time. Industrial production rose 7 percent in 1973 and unemployment fell from 3.7 percent in 1972 to 2.6 percent in 1973 and 1974 (chart 1). Investment, however, did not rise significantly and the boom was short-lived. The oil crisis combined with a sharp reversal in monetary policy to bring the expansion to an end. By 1975, industrial production was back to its 1970 level.

During this time, however, inflation accelerated, reaching 25 percent per year in 1975. Some blamed the inflation on the ofl price rise; the major cause, however, was the money stock increases of $1972-73$ (see chart 3 ). As a result of this extremely fast money growth, inflation in Britain went much higher than in other industrial countries. In the United States, for example, it was about 11 percent in 1974 and about 9 percent in 1975.

\section{A Tightening of the "Corset"}

The reversal of monetary policy in December 1973 took the form of a return to quantitative ceilings on deposits. This scheme, which became known as the "corset," restricted banks' ability to compete for interest-bearing time deposits. A maximum percentage growth tate was specified for banks' interest-bearing eligible liabilities. If a bank exceeded this growth rate, it was required to place non-interest-bearing "Supplementary Deposits" with the Bank of England (much

${ }^{7}$ For a retrospective assessment of the corset, see Bank of England Quarterly Bulletin (March 1982). pp. 74-85. 
like the Fed's required reserves/. The corset remained in force until June 1980 lapart from two breaks: February 28, 1975, to November 18, 1976, and August 11, 1977, to June 8,1978 ).

The upsurge of inflation became a major political concern. A voluntary wage restraint policy was introduced in mid-1975, and a commitment was made that money supply growth would cease to be a source of inflationary pressure in the economy $A$ target range for the growth rate of sterling M3 was introduced in 1976 by the Labour Chancellor Dennis Healey. ${ }^{8}$ The practice of announcing targets has continued to date. The targets have generally been achieved except in periods following relaxation of the corset.

While the inflationary monetary expansion of 197173 was moderated after the end of 1973 , the fiscal deficit got bigger. From a financial supplus in 1970 , public sector finances deteriorated to a position where in 1975 public sector borrowing exceeded 10 percent of GNP. This was partly due to the policies introduced by the Heath government, but also to the efforts of the subsequent Labour government, elected in February 1974 , to hold down nationalized industry prices as well as those of some foods. This involved increased subsidies. The argument, initially accepted in official cir cles, was that an increased budget deficit represented an appropriate offset to the impact of the oil price rise.

By 1976, the size of the budget deficit had become a major public issue. A crisis was triggered by a substantial fall in the value of the pound. An application was made to the International Monetary fund (IMF) for a loan to increase foreign exchange reserves. Why this was necessary is not clear, since the pound was floating, but the government introduced a major package of public spending cuts in order to meet IMF conditions for the loan. While current government expenditures on goods and services were held back to a noticeable degree, the major impact of the cuts was in public sector investment programs (see chart 4).

Despite the tightening of fiscal policy after 1976, the economy exhibited moderately strong real growth through 1979. Growth rates of real GDP (gross domestic product, which is gross national product less net income from abroad/ were in the 2 percent to 3 percent range. The expansion was aided somewhat by a tem-

\footnotetext{
${ }_{8}$ It was first announced that money growth would henceforth be noninflationary. A forecast for sterling $M 3$ was then released. Only fater did the forecast form the basis of a target range.

${ }^{9} \mathrm{~A}$ further problem was created by the fact that up to 1975 government expenditures were planned in real terms. When prices rose, nominal expenditure was increased to compensate. Subsequently, cash lim" its were introduced for public spending.
}

porary relaxation of monetary policy in the second half of 1977 and first half of 1978. Partly this expansion resulted from the removal of the corset; it also was induced, however, by substantial foreign exchange intervention to stop the pound from appreciating. U.K. foreign exchange reserves rose from $\$ 3.4$ billion at the end of 1976 to $\$ 20.1$ billion by the end of 1977 . This intervention was clearly reflected in the rapid growth of M1 (see chart 3). ${ }^{10}$

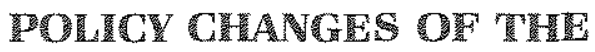 THATCINPT GOVERNMENT}

Whereas the 1970-74 Conservative government of Edward Heath had embarked on a money growth and public spending-led boom, Mrs. Thatcher came to power in 1979 committed to a very different strategy. The Thatcher govermment had two major goals. One goal was to reduce the level of public spending; in order to both eliminate the budget deficit and facilitate lower levels of taxation. This would reverse the alleged crowding out of private sector activity by the public sector and would restore the incentives necessary for industrial growth. Second, inflation was to be squeezed out of the economy by a gradual reduction of the rate of growth of the money stock. ${ }^{11}$

In June 1979, Sir Geoffrey Howe, Mrs. Thatcher's Chancellor of the Exchequer for her first government (May 1979-June 1983), introduced a budget that lowered personal direct taxes and raised indirect taxes. The budget also included a rise in the tax on North Sea oil producers. Planned public expenditures were cut. The target range for the growth rate of sterling M3 was set at 7-11 percent, only 1 percent lower than that set by the previous labour government. At the same time, however, the Bank of England's Minimum Lending Rate (MLR) was raised from 12 percent to 14 percent land later raised to 17 percent in November) ${ }^{12}$

The June 1979 policy changes were intended to reduce inflation, which had begun to rise again in 1979 . This macroeconomic policy strategy was formalized in

\footnotetext{
${ }^{10}$ This experience with intervention did much to convince the authorities that holding down the value of the pound without generating a rapid rise in the money supply was impossible.

${ }^{11}$ The intention of eliminating inflation solely by monetary policy rather than incomes policies was one reason why Mrs. Thatcher earned the monetarist label. The nature of monetarism is outined in Batten and Stone (1983). For a discussion of how views about macroeconomic policy had changed over time both in Britain and the United States, see Alt and Chrystal (1983).

${ }^{12}$ Bank Rate was renamed Minimum Lending Rate in 1971. It was intended to be related to market rates, though from time to time it was still used as a policy instrument. See Hall.
} 


\section{Chort 4 \\ Government Transfers, Consumption and Investment as a Percent of GDP}

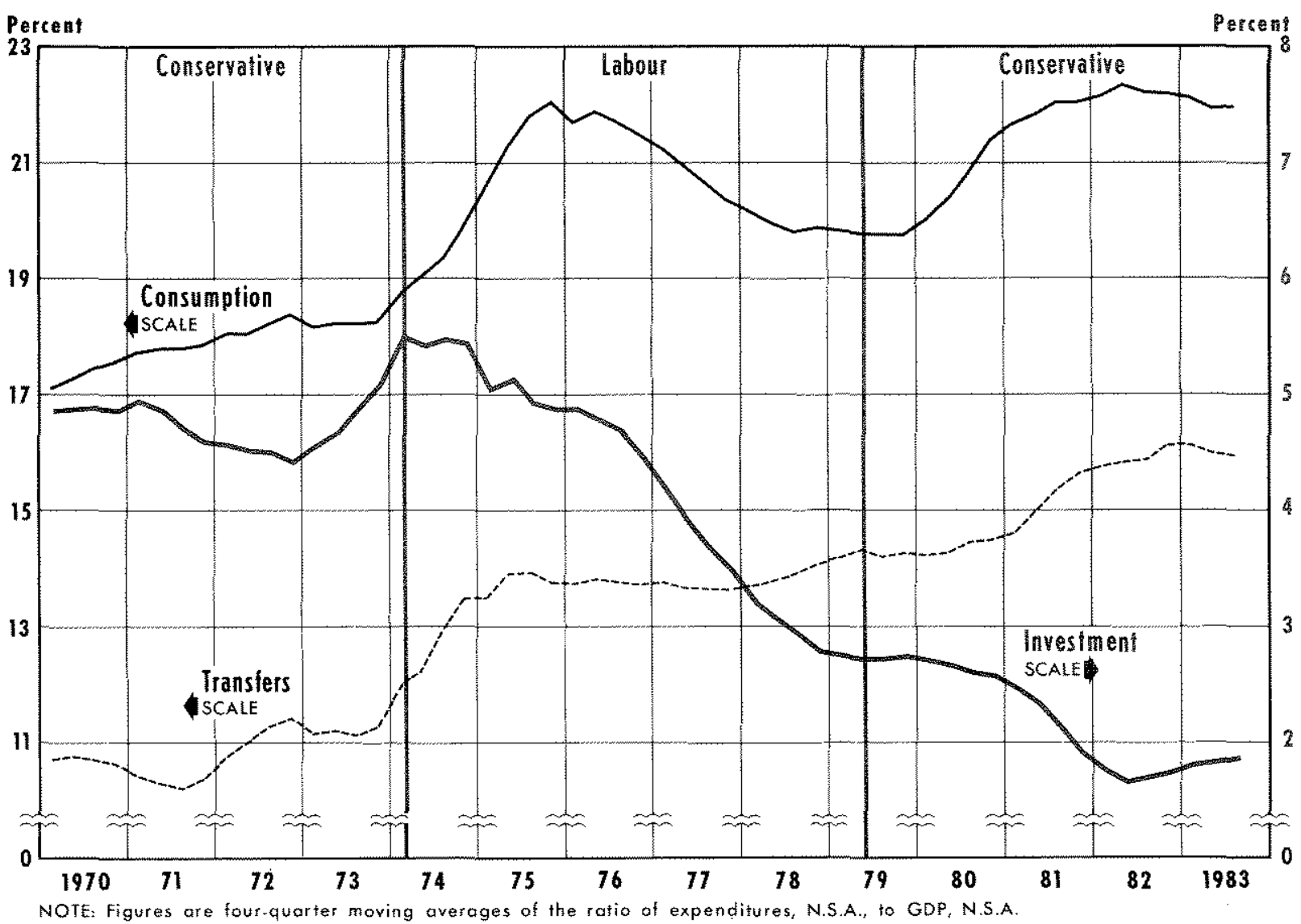

the March 1980 budget into a so-called Medium Term Financial Strategy (MTFS), which involved planned reductions in public spending over a four- of five-year horizon to reduce the budget deficit as a proportion of GDP. Reductions in tax rates also were considered. Monetary growth targets were to be reduced gradually over the same period, though there was no change in the range for $1980 / 81 .^{13}$

The MTFS was effectively abandoned almost immediately. The Public Sector Borrowing Requirement target for $1980 / 81$, set in the March budget, was $£ 81 / 2$ billion. By November 1980, the forecast was revised upward to $£ 11 / 2$ billion. The expansion of public spending was due partly to high wage settlements in the public sector and partly to an unexpected rise

\footnotetext{
${ }^{13}$ Budgets are normally submitted in March. They apply for the following financial year which runs April to April. The convention used here is that $1980 / 81$ refers to the financial year April 1980 to April 1981.
}

in unemployment. ${ }^{1 / 4}$ The abandonment of the conset in June 1980 led to growth rates of sterling M3 well in excess of the upper target leve. ${ }^{1.5}$

While Mrs. Thatcher intended to cut both taxes and public spending, the opposite generally has occurred.

\footnotetext{
${ }^{14}$ The previous Labour government had set up a Pay Comparability Commission to inquire into public sector pay. This commission recommended substantial pay raises for many groups. Mrs. Thatcher honored these recommendations before winding up the commission and substituting a public sector "pay norm."

${ }^{15}$ Buiter and Miller (1981) argued that monetary policy in Britain was too tight and resulted in an excessive appreciation of sterling. in Buiter and Miter (1983), however, they admit that the evidence is not consistent with a monetary overshooting hypothesis. Indeed, they express concern for the credibility of a monetary policy that frequently exceeded targets. Since 1979, sterling $M 3$ growth has consistently exceeded the inflation rate. $\mathrm{M} 1$ growth looks more restrictive, though this also is distorted by the ending of the corset. The freeing of banks to compete for time deposits led to a switch from checking accounts to time deposits. This substitution is voluntary and would not normally be considered to represent policy tightening.
} 
Chart 5

\section{Government Tax Revenues as a Percent of GDP}

Percent

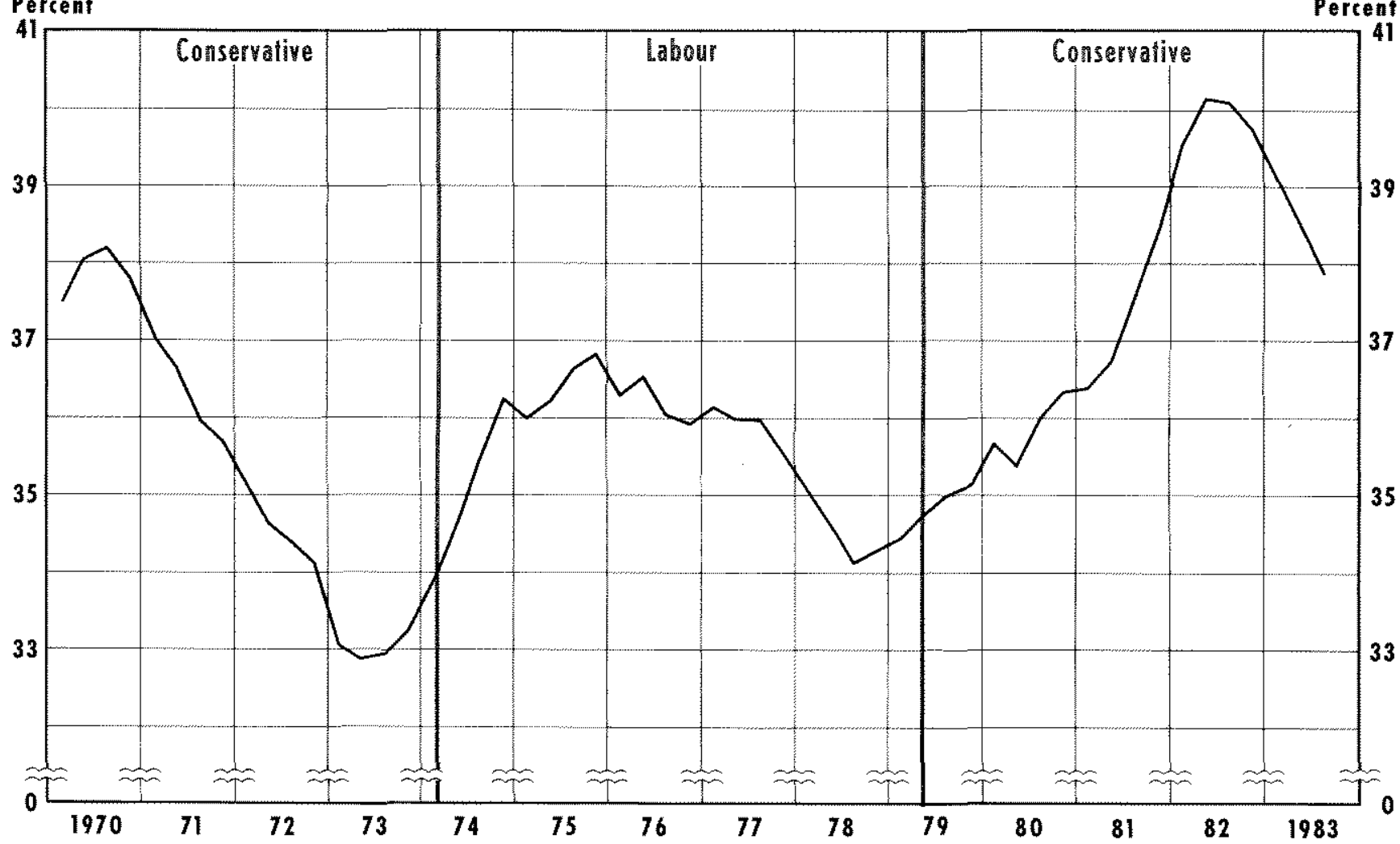

NORE; Figures are four-quarter moving averages of the ratio of tax revenues, N.S.A., to GDP, N.S.A.

Tax revenue, for example, grew as a proportion of GDP until late 1982 (chart 5 I. $^{16}$ Similarly, both real government consumption (current spending on goods and services) and real transfer payments have risen as a proportion of GDP since 1979 (chart 4). The major exception on the expenditure side is govemment investment (chart 4), which was cut until mid-1982. The cuts achieved in this category by the Thatcher government, however, were much smaller than those introduced by the previous Labour government.

\section{ARE POLICY CHANGES PRIMARILY RESPONSIBLE?}

It is hard to look at what happened in Britain after 1979 and be comfortable with the story that policy

\footnotetext{
${ }^{16}$ Revenue from taxes on North Sea oil producers has contributed significantly to this. In 1978, the yield on Petroleum Revenue Tax was close to zero. In 1983, the taxes on North Sea oil yielded $\{6.1$ billion which was 13.5 percent of total tax revenue.
}

changes made by the Thatcher govemment are entirely responsible. We already have seen that unemployment in 1983 reached a level well over double that associated with the $1973-75$ recession. Yet monetary policy was probably no tighter in the Thatcher years than in the previous recession.

Fiscal policy, if anything, was tighter in the 1975-78 period than in the first three years of the Thatcher government. Table 1 presents the change in budget deficit as a proportion of GDP. The first column is based on unadjusted figures. The second column attempts to identify changes due to discretionary policy rather than cyclical factors. It also weights the tax and expenditure changes according to their impact on demand. An allowance for the fact that some taxes came from oil, which would have a different impact on demand from, say, personal income taxes, is therefore included in this measure; thus, it provides a better indicator of fiscal policy stance. Negative figures reflect a reduction of the deficit and, therefore, a tightening of policy. 


\section{Table 1 \\ Change in the British Budget Deficit as Percent of GDP}

\begin{tabular}{|c|c|c|}
\hline & ontalsted & 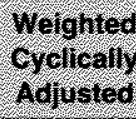 \\
\hline 197475 & $257 \%$ & $1.5 \%$ \\
\hline 197676 & 026 & $-1 / 6$ \\
\hline $1976 \pi$ & 2.779 & $(1.32$ \\
\hline 197778 & 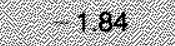 & 220 \\
\hline 197879 & 081 & 058 \\
\hline 187960 & 097 & 056 \\
\hline 190068 & 0.87 & 0.5 \\
\hline 196468 & 2760 & $2+210$ \\
\hline $1602 \% 8$ & 0.60 & 0.0 \\
\hline 1908.64 & 0.10 & 0.30 \\
\hline
\end{tabular}

What emerges from these figures is that fiscal policy was mildly restraining in $1979 / 80$ and $1980 / 81$. It was tighter in 1981/82, but has been more or less neutral since then. It is noticeable, however, that the fiscal policy of the Thatcher government has been less restrictive than that of the previous Labour government in the three financial years $1975 / 76$ to $1977 / 78$, when the cumulative fall in the deficit as a percent of GDP (weighted and cyclically adjusted) amounted to 4.7 percentage points. The fall under Mrs. Thatcher in the three years $1979 / 80$ through $1981 / 82$ totaled only 3.2 percentage points.

\section{WAS THE WORLD RECESSION PRIMARILY RESPONSIBLE?}

Britain's economy exports about 25 percent of its GDP. It is conceivable that a decline in world demand could reduce the demand for British exports enough to cause a contraction of manufacturing production. No doubt the worldwide recession of the early 1980 s is partly to blame; however, it does not seem to be the main event: the decline in manufacturing in Britain preceded the world recession by several months.

Table 2 shows that world trade in manufactured goods grew strongly through 1980, slowed in 1981, then declined marginally in 1982. The decline in sales of British manufactured goods, however, dates from 1979 at the latest, and the adjustment of production was

\section{Table 2 \\ World Trade, Production and Unemployment}

\begin{tabular}{|c|c|c|c|c|c|}
\hline & 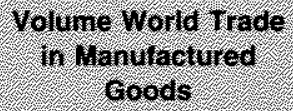 & $\begin{array}{l}\text { Indu } \\
\text { produ }\end{array}$ & (196) & Unemp & girent \\
\hline & $1975 \cdot 100$ & ofor & $1 / 1$ & Oedo & U. \\
\hline 1975 & 100 & 100 & 100 & $5.2 \%$ & $47 \%$ \\
\hline 1976 & 112 & 109 & 103 & 53 & 60 \\
\hline 1977 & 17 & 13 & 106 & 53 & 68 \\
\hline 1978 & 123 & 17 & 112 & 52 & 63 \\
\hline 1979 & 180 & 129 & 196 & 5. & 6.6 \\
\hline 1980 & 137 & 123 & 108 & 88 & 70 \\
\hline 1881 & 130 & 128 & 104 & 67 & 107 \\
\hline 1982 & 136 & 14 & 106 & 62 & 124 \\
\hline 1983 & na & 122 & 109 & 87: & $12 \mathrm{~g}$ \\
\hline & 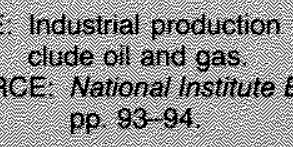 & res & & ect. & \\
\hline
\end{tabular}

largely complete by the end of $1980 .{ }^{17}$ In both 1979 and 1980, world trade in manufactured goods rose strongly.

The figures for industrial production tell a similar story: Organization for Economic Cooperation and Development $(\mathrm{OECD})$ industrial production rose strongly in 1979, leveled off in 1980 and 1981 and declined in 1982. British industrial production fell about two years before the fall in the OECD figure, and by a considerably larger amount. ${ }^{18}$

Before 1976, unemployment in Britain had typically been below the OECD average. From 1976 through 1979. Britain's unemployment rate was a little higher, but followed a similar pattern to the OECD average. Since 1979, Britain's unemployment has risen much further than the OECD average.

Thus, there is no strong case for believing that the world recession provides an adequate explanation of the contraction in Britain in 1980, even when combined with the Thatcher government's monetary and fiscal policies. Indeed, the world recession was most severe in 1982, a year in which Britain's manufacturing production actually recovered somewhat.

\footnotetext{
${ }^{17}$ Manufacturers' stocks of unsold output rose sharply in 1979 indicating a slump in sales. See National Institute Economic Review (February 1984), p. 11, chat 5. Production was subsequently cut back and stocks run down through 1980 .

${ }^{1}$ Industrial production is a broader aggregate than manufacturing, it includes ofl production among other things.
} 
Chart 6

\section{Oil and Manufacturing Trade Balance}

Millions of pounds

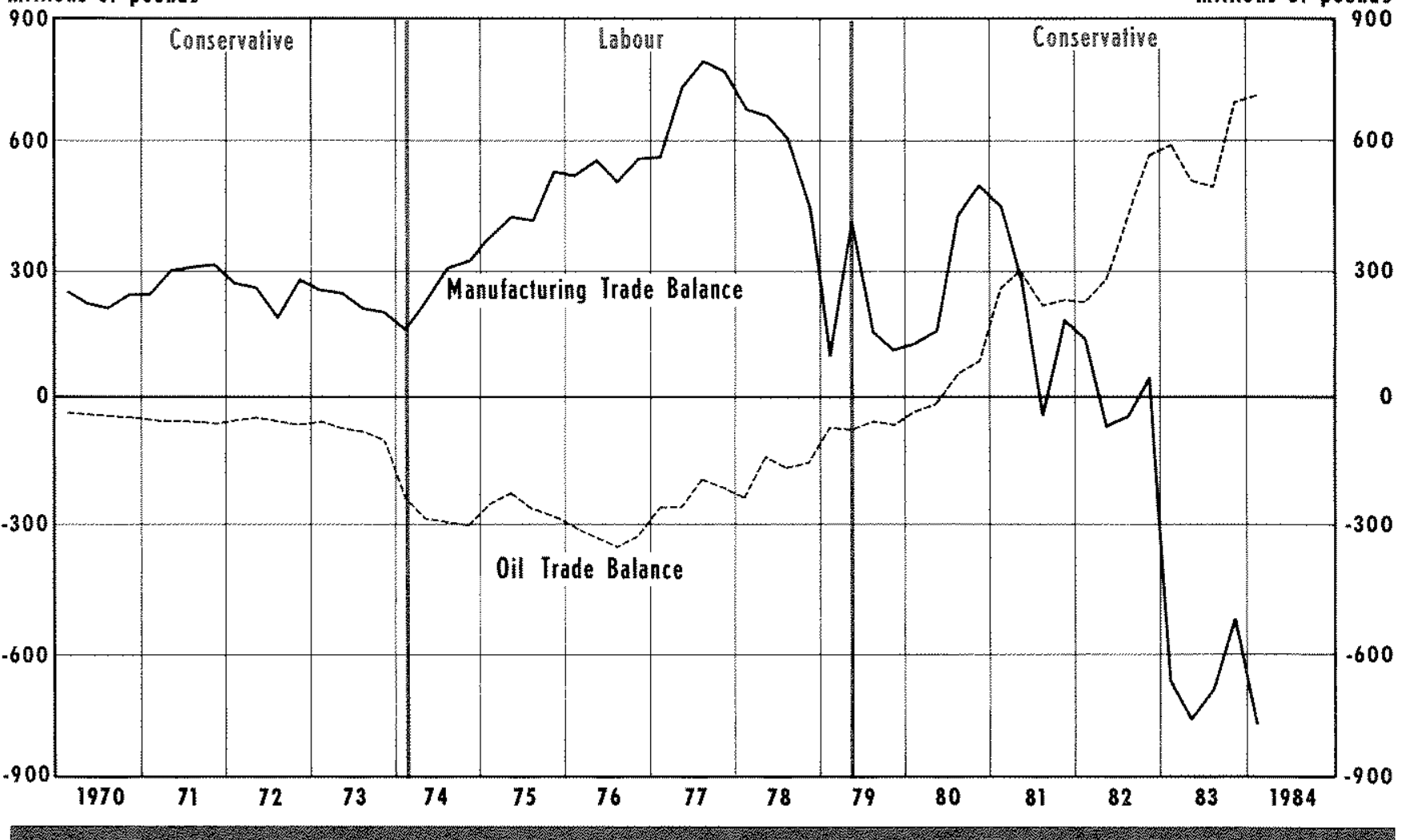

\section{TIE NOPRTI SEA OLL EXPLANATION}

The emergence of Britain as a major oil producer provides an explanation of some of the changes that occurred in the British economy over the past five years ${ }^{19}$ Up to mid-1976, Britain was entirely dependent upon imported oil; in 1980, Britain became a net exporter of oil. Following such a structural change in the supply side of the economy, the trade balance in manufactured goods, according to theory, would move in the opposite direction of the oil balance. ${ }^{20}$ The force

\footnotetext{
${ }^{19}$ Some commentators such as Buiter and Miller $(1981,1983)$. Niehans (1981) and Darby and Lothian (1983) have dismissed the effects of North Sea ofl. However, Forsyth and Kay (1980) argued that oil production would lead to a sizable contraction in manufacturing. Bond and Knöbl (1982), Laney (1982) and McGuirk (1983) all provide evidence that oil has substantially worsened the competitiveness of U.K. manufacturing. See Bank of England Quarterly Bulfetin (1982), pp. 56-73, for a description of North Sea oll resources.
}

${ }^{20}$ See, to example, Corden and Neary (1982). that brings this about is an appreciation of the exchange rate, which raises the price of domestic manufactured goods relative to overseas competitors' prices. Consequently, domestic consumers buy a higher proportion of foreign-produced goods, and foreigners buy relatively fewer domestic-manufactured exports. Thus, the manufacturing sector contracts. ${ }^{21}$

Chart 6 shows the oil trade balance and the manufacturing trade balance. Chart 7 shows the dollarpound exchange rate and the relative wholesale price of British manufactured goods compared with other

\footnotetext{
${ }^{27}$ Sirictly speaking, this contraction need only be relative to the rest of the economy. What has to be explained is the switching of spending from home-produced to foreign-produced manufactured goods. Our claim is that this was largely a relative price effect resutting from the oil-related decline of competitiveness of British manufacturing.

There are relative price effects among inputs as well as outputs. $A$ rise in real wages has caused manufacturers to economize on labor for given output levess. Output per person employed in U.K. manufacturing rose 15 percent between the end of 1980 and mid-1983 Thus, the decline in employment in manufacturing has been greater than the output loss alone would have led to.
} 


\section{Chort 7}

\section{Dollar/Pound Exchange Rate and Relative Wholesale Prices}

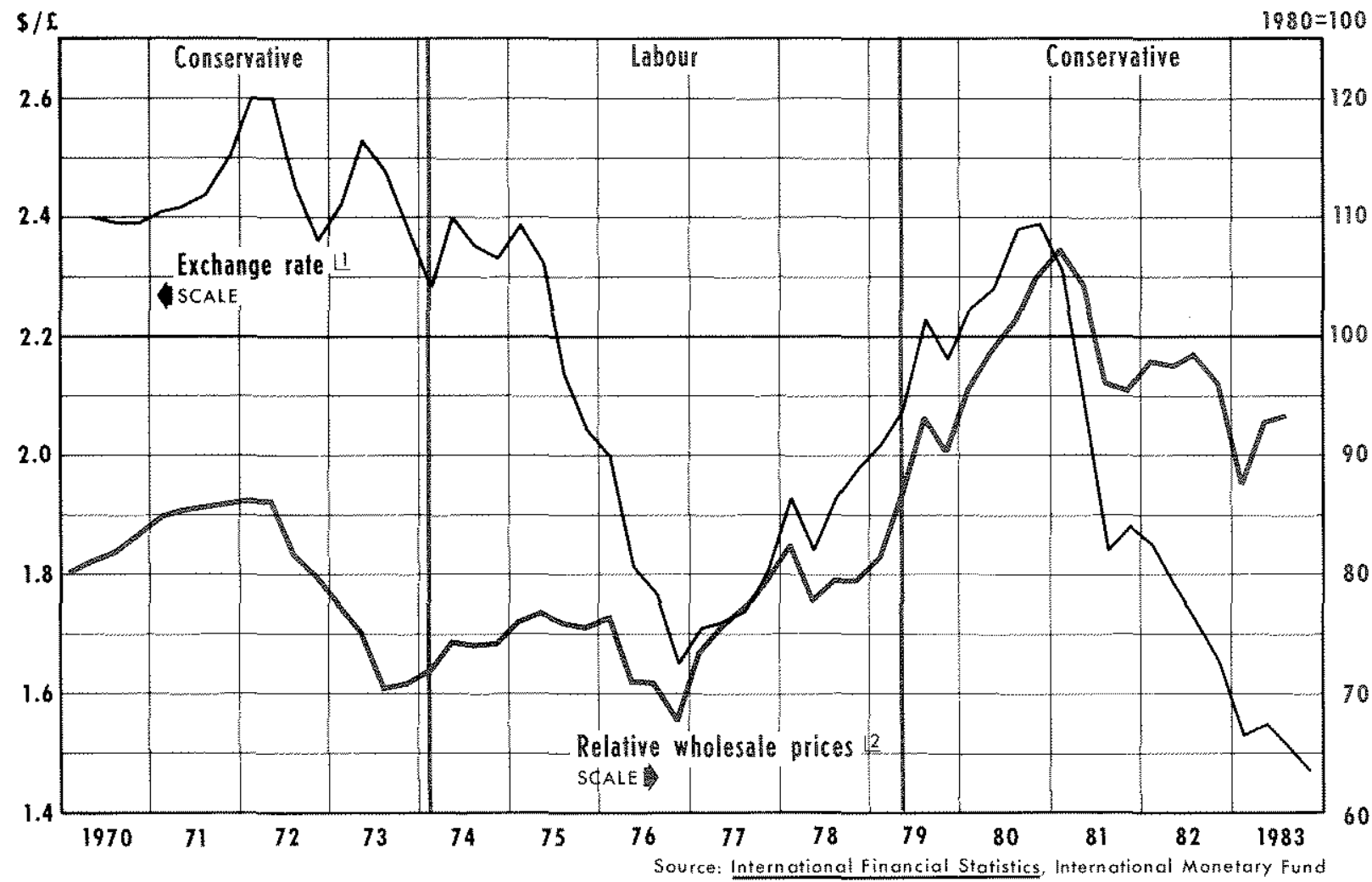

11 Dota gre overages of daty figures.

12 Wholescle prices ore for manufacturing relative to 13 other industrial countries.

industrial countries. ${ }^{22}$ Until 1973, there was a small surplus in manufactured trade and a small deficit in oil trade. As the oil deficit grew, so did the manufactured goods export surplus. From III/1976 on, the oil deficit shrank, and was eliminated in 1980 . By $1 / 1984$, there was a substantial oil surplus.

The manufacturing surplus initially continued to increase as the pound appreciated after $1976{ }^{23}$ As

\footnotetext{
${ }^{22}$ Niehans, and Darby and Lothian akgue that the appreciation of stering was due to slow base money growth in the early years of the Thatcher government. This is implausible. Why, for example, was sterling appreciating for two years before Mrs. Thatcher came to power, and why did if depreciate in 1981 when base growth continued to slow? None of the monetary explanations of the exchange rate can explain a sustained rise in relative goods prices over a long period of time, such as that evident in chart 7 . Such changes require structural explanation such as is offered by North Sea oil, Many commentators presumed that monetary policy was tight simply because sterling was appreciating. Laney offers evidence that monetary explanations of the U.K. exchange rate broke down after 1977. The price of oil is an important explanatory variabie after that date. He also shows that other new oil producers have had comparable experiences. Thus, the event of significance in 1979 may not be the election of Mrs. Thatcher but rather the rise in the price of oll.

${ }^{23}$ As the currency appreciates, the stering price of imports falls, In the short run, this improves the manufacturers' trade balance because
}

sterling appreciated further, however, relative demand for British and foreign goods shifted far enough to compensate for the relative rise in price of British goods. After mid-1977, the surplus in manufactured

the same volume of imports costs less. However, as spending patterns adjust to the new relative prices, the volume of exports starts to fall relative to the volume of imports. Once the volumes adjust more than the prices, the balance in manufactured goods starts to decline. This is just the reverse of the "J curve" effect of a devaluation. It arises because demand elasticities are smaller in the short run than in the long run. Because of this, the exchange rate may appreciate "too far" in the process of adjustiritg to the oil surplus. That is to say that the rise in the relative price of manufactured goods required in equilibrium is less than that actually experienced during transition. This is consistent with events in Britain where relative wholesale prices (chart 7) overshot their ultimate level. This is a different kind of overshooting from that associated with an unexpected tightening of monetary policy analyzed by Dornbusch (1976). The appreciation of the exchange rate is brought about not just by the impact of the changing oil balance on the current account but also by capital inflows which reinforce the process. The 1979 oll price rise boosted a process already under way. McGuirk estimates that a 23 percent fall in competitiveness was required in equilibrium to adjust the U.K. trade balance to the effects of oil at the 1980 oll prices. At the 1978 price of oit, this was only 12 percent. A fall in competitiveness is a rise in the relative price of British goods. This is sometimes referred to as a rise in the "real" exchange rate. 
goods fell sharply, until by I/1984 there was a substantial deficit in manufactured goods trade, roughly equal to the oil surplus.

In short, we have an explanation of events in Britain that requires neither a major contraction in domestic aggregate expenditure nor a major slump in total world demand to explain the collapse of manufacturing industry in Britain. The dominant factor was a major switch in spending patterns resulting from the rise in relative price of British manufactured goods. The proportion of domestic demand for these goods satisfied by imports rose sharply, while exports of manufactured goods stagnated. The volume of manufactured exports was about the same in 1983 as it was in 1976. Over the same period, the volume of manufactured goods imported rose 63 percent.

\section{CONCLUSION}

The government of Margaret Thatcher has been blamed by its critics for causing a major contraction of activity in Britain by applying monetarist policies. Without quibbling over whether those policies were indeed monetarist, this article argues that the case for blaming the rise in unemployment and the contraction of manfuacturing on deflationary aggregate demand policies is not a strong one, even if one allows for the impact of the world recession. Rather, the production and sale of North Sea oil have had a bignegative impact on the British manufacturing sector. The production of oil and the subsequent rise in its price caused an appreciation of steriing and a rise in the relative price of British manufactured goods. As a result, British manufactured goods became uncompetitive and production contracted sharply. Thus, it is impossible to write a balanced history of the British economy over the last few years without reference to North Sea oil production.

\section{REFERENCES}

Alt, J. E., and K. Alec Chrystal. Political Economics (University of California Press and Wheatsheaf, 1983).

Bank of England Quarterly Bulletin, vol. 22, no. 1 (March 1982).

Batten, Dallas S., and Courtenay C. Stone. "Are Monetarists an Endangered Species?" this Review (May 1983), pp. 5-16.

Bond, Marian E., and Adabert Knöbl. "Some Implications of North Sea Oil for the U.K. Economy," International Monetary Fund Staff Papers, vol. 29, no. 3 (September 1982), pp. 363-97.

Buiter, Willem, and Marcus Miller. "The Thatcher Experiment: The First Two Years," Brookings Papers (2:1981), pp. 315-79.

. "Changing the Rules: Economic Consequences of the Thatcher Regime," Brookings Papers (2:1983), pp. 305 65 .

Corden, W. Max, and J. Peter Neary. "Booming Sector and Dein-

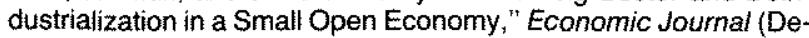
cember 1982), pp. 825-48.

Darby, Michael R., and James R. Lothian. "British Economic Policy Under Margaret Thatcher: A Midterm Examination," CamegieRochester Conference Series on Public Policy (North-Holland, 1983), pp. 157-207.

Dornbusch, Rudiger. "Expectations and Exchange Rate Dynamics," Journal of Political Economy, vol. 84, no. 6 (December 1976), pp. 1161-76.

Forsyth, P. J., and J. A. Kay. "The Economic Implication of North Sea Oil Revenues," Fiscal Studies, vol. 1 (July 1980), pp. 1-28.

Gould, Bryan, John Mills, and Shaun Steward. Monetarism or Prosperity (Macmillan Press Ltd., 1981).

Hall, Maxmillian. Monetary Policy Since 1971: Conduct and Performance (Macmilan Press Lid., 1983).

Henry, S. G. B., and P. A. Ormerod. "Incomes Policy and Wage intlation: Empirical Evidence for the U.K. 1961-1977," National Institute Economic Review, no. 85 (August 1978), pp. 31-39.

Kaldor, Nicholas. The Scourge of Monetarism (Oxford University Press, 1982).

Laney, Leroy O. "How Contagious is 'Dutch Disease'?" Federal Reserve Bank of Dallas Economic Review (March 1982), pp. 3-12.

McGuirk, Anne K. "Oil Price Changes and Real Exchange Rate Movements Among Industrial Countries," International Monetary Fund Staff Papers, vol. 30 , no. 4 (December 1983), pp. $843-84$.

National Institute Economic Review, no. 107 (February 1984).

Niehans, Jürg. "The Appreciation of Sterling-Causes, Effects and Policies," Money Study Group Discussion Paper (Social Science Research Council, 1981). 